\title{
Comparison of Stored Umbilical Cord Blood and Adult Donor Blood: Transfusion Feasibility
}

\author{
Saklanan Kordon Kanının Erişkin Bağışçı Kanıyla Karşılaştırılması: \\ Transfüzyon için Kullanılabilirlik Çalışması
}

\author{
Rola Sahyoun-Tokan ${ }^{1}$, Saadet Arsan ${ }^{2}$, Ömer Erdeve 2 , Nuri Solaz ${ }^{6}$, Aslihan Avci ${ }^{4}$, \\ Serenay Elgün-Ülkar ${ }^{4}$, Elif Gülyapar ${ }^{7}$, Zeynep Üstünyurt' ${ }^{7}$, Zeynep Bıylklı ${ }^{5}$, Sabri Kemahli ${ }^{3,6}$ \\ ${ }^{1}$ Ankara University, Faculty of Medicine, Department of Pediatrics, Ankara, Turkey \\ ${ }^{2}$ Ankara University, Faculty of Medicine, Department of Pediatrics, Division of Neonatology, Ankara, Turkey \\ ${ }^{3}$ Ankara University, Faculty of Medicine, Department of Pediatrics, Division of Pediatric Hematology, Ankara, Turkey \\ ${ }^{4}$ Ankara University, Faculty of Medicine, Department of Biochemistry, Ankara, Turkey \\ ${ }^{5}$ Ankara University, Faculty of Medicine, Department of Biostatistics, Ankara, Turkey \\ ${ }^{6}$ Ankara University, Faculty of Medicine, Serpil Akdağ Blood Center, Ankara, Turkey \\ ${ }^{7}$ Dr. Zekai Tahir Burak Women's Hospital, Ankara, Turkey
}

\begin{abstract}
Objective: This study aimed to compare the storage properties of red blood cell (RBC) concentrates of umbilical cord blood (UCB) and adult donor blood (ADB), and to evaluate the feasibility of UCB-RBC concentrate as an autologous source for blood transfusion in very low birth weight (VLBW) preterm neonates.
\end{abstract}

Material and Methods: In all, 30 newborn (10 preterm, 20 full term) UCB and 31 ADB units were collected. RBC concentrates were stored and compared with regard to $\mathbf{p H}$, potassium $\left(\mathrm{K}^{+}\right)$, 2,3-biphosphoglycerate (2-3-BPG), adenosine tri-phosphate (ATP), plasma $\mathrm{Hb}$, and bacterial contamination on $\mathrm{d} 1,21$, and 35 of storage.

Results: The $\mathrm{K}^{+}$level increased with time and differed significantly between storage $\mathrm{d} 1$ and 21 , and between storage d 1 and 35 in both the UCB and ADB units. Initial and d $21 \mathrm{~K}^{+}$levels were higher in the UCB units than in the ADB units. The 2,3-BPG level did not differ significantly between the UCB-PRC and ADB-PRC samples. After $35 \mathrm{~d}$ of storage both UCB-PRC and ADB-PRC samples exhibited significant differences from the initial free Hb, intracellular ATP, and pH values. Significant differences in intracellular ATP and $\mathrm{pH}$ were also observed between the UCB-PRC and ADB-PRC samples.

Conclusion: The volume of harvested and prepared UCB-PRC can be used for some of the blood transfusions required during the neonatal period and thus may decrease the number of allogeneic transfusions, especially in preterm newborns. The hematological and biochemical changes that occurred in UCB during storage were comparable with those observed in ADB, and do not pose a risk to the immature metabolism of neonates. UCB-RPC prepared and stored under standard conditions can be a safe alternative RBC source for transfusions in VLBW newborns.

Key Words: Transfusion, Newborn, VLBW preterm, Umbilical cord blood, Blood storage

Address for Correspondence: Sabri KEMAHLI, M.D.,

Ankara Üniversitesi, Tıp Fakültesi, Çocuk Sağlığı ve Hastalıkları Anabilim Dalı, Cebeci 06100 Ankara, Turkey

Phone: +90 3125956635 E-mail: kemahli@medicine.ankara.edu.tr

Received/Geliş tarihi : February 3, 2011

Accepted/Kabul tarihi : January 30, 2012 


\section{Özet}

Amaç: Çalışmada kordon kanı ile erişkin bağış̧̧ı kanlarından elde edilen eritrosit süspansiyonlarının özelliklerini ve saklama sırasında oluşan değişiklikleri izleyerek, kordon kanından elde edilen eritrosit süspansiyonlarının çok düşük doğum ağırlıklı yenidoğanlarda otolog bir transfüzyon kaynağı olarak kullanılabilirliğini değerlendirmek amaçlanmıştır.

Gereç ve Yöntemler: 30 yenidoğan ( 20 preterm, 10 term) kordon kanı ile 31 erişkin bağış̧̧ kanı toplandı. Hazırlanan eritrosit süspansiyonları standard koşullarda saklanarak 1., 21. ve 35. günlerde $\mathbf{p H}$, potasyum ( $\left.\mathrm{K}^{+}\right)$, 2,3-BPG, adenozin trifosfat (ATP), plazma Hb ve bakteriyel kontaminasyon bakımından incelendi.

Bulgular: Potasyum değerlerinin zamanla artarak, hem kordon kanı hem de erişkin kanlarında 1.-21. ve 1-35. günler arasında anlamlı farklar saptandı. İlk ve 21. Gün değerlerinin kordon kanında erişkin kanlarından daha yüksek olduğu saptandı. 2,3-BPG değerleri kordon kanı ve erişkin kanlarında anlamlı fark göstermedi.Saklamanın 35. gününde hem kordon kanı hem de erişkin kanlarında serbest $\mathrm{Hb}$, ATP ve pH değerlerinin ilk değerlere gore anlamlı fark gösterdiği belirlendi.Bu parametreler açısından kordon kanı ve erişkin kanı grupları arasında da fark olduğu görüldü.

Sonuç: Toplanan ve hazırlanan kordon kanı eritrosit süspansiyonları yenidoğan dönemindeki transfüzyon gereksinimini kısmen karşılayabilir ve böylece allogeneik transfüzyonları azaltabilir. Saklama sırasında oluşan hematolojik ve biyokimyasal değişiklikler erişkin bağışçı kanlarındakilere benzerlik göstermekte olup yenidoğan metabolizması için bir risk oluşturacak düzeyde değildir. Kordon kanından hazırlanıp standart koşullarda saklanan eritrosit süspansiyonlanı çok düşük doğum ağırlıklı yenidoğanlar için bir seçenek olabilir.

Anahtar Sözcükler: Transfüzyon, Yenidoğan, Çok düşük doğum ağırlıklı preterm, Kordon kanı, Kan saklama

\section{Introduction}

The majority of neonates usually have uncomplicated hematological adaptation to their physiological circumstances following delivery; however, very premature neonates are prone to suffer from mild to severe anemia, which must be corrected. At present, adult donor blood $(\mathrm{ADB})$ is used for neonates that require transfusion $[1,2,3]$. Although the risk of transfusion-associated infections has been significantly reduced due to changes in blood collection, testing, processing, and storage, the risks associated with blood transfusion have not been reduced to zero and these risks are well documented $[4,5]$.

Umbilical cord blood (UCB) is emerging as an option for autologous red cell transfusion in low-birth-weight (LBW) and preterm infants. Its autologous nature negates the risks inherent in transfusion from adult donors; however, few studies have compared the properties of red blood cell (RBC) concentrates from UCB and ADB, and the changes that occur in each during storage. The aim of the present study was to compare the storage properties of $\mathrm{UBC}$ and $\mathrm{ADB} \mathrm{RBC}$ concentrates, and to evaluate the feasibility of UBC RBC concentrates as an autologous source of blood transfusion in very low birth weight (VLBW) preterm neonates.

\section{Material and Methods}

\section{Participants}

ADB samples were collected at Ankara University, Ser- pil Akdağ Blood Center, Ankara, Turkey, from 31 healthy male and female donors that met the standard blood donor criteria and provided informed consent to participate in the study. The donors were tested to rule out hepatitis B, hepatitis C, HIV, and syphilis infection. UCB was collected at Zekai Tahir Burak Women's and Maternity Hospital, Ankara, Turkey, from 20 full-term and 10 preterm infants (gestational age $<32$ weeks) that were delivered via caesarean section; informed consent was obtained from their parents before delivery.

Exclusion criteria for the collection of UCB were maternal viral or bacterial infections, including suspected chorioamnionitis (defined by the presence of purulent amniotic fluid, C-reactive protein [CRP] $>10 \mathrm{mg} \mathrm{L}^{-1}$, or an immature to total white blood cell (I:T) ratio in the mother $>0.15)$. None of the blood units tested in this study were used for transfusion.

The study protocol was approved by the ethics committees of Ankara University, School of Medicine and Zekai Tahir Burak Women's and Maternity Hospital, and was performed in accordance with the Declaration of Helsinki.

\section{Blood collection}

Standard units $(450 \pm 45 \mathrm{~mL})$ of blood were drawn from each adult donor into a main blood bag that contained $63 \mathrm{~mL}$ of citrate-phosphate-dextrose (CPD). Pediatric blood bag sets (Kansuk Laboratuarı, Istanbul Turkey) were used for UCB collection. As standard blood bags con- 
tain CPD solution at a ratio of $1: 7$ for $450 \mathrm{~mL}$ of whole blood, the volume of CPD for use in UCB collection bags was calculated using the same ratio and an estimated maximum UCB volume of $140 \mathrm{~mL}$; thus, UCB was collected into bags containing $21 \mathrm{~mL}$ of $\mathrm{CPD}$.

Placental blood collection was performed using a specifically modified placental blood collection system. Before placental blood collection the blood collecting system's primary bag was placed approximately $1 \mathrm{~m}$ below the level of the placenta. Placental blood was collected immediately after birth, with the placenta in utero. Cord clamping was performed immediately after the baby was born and then the puncture site was identified approximately $10 \mathrm{~cm}$ from the placenta-cord interface. The umbilical cord vein was then punctured with a cannula attached at the longer collection tube of the collection system. The collecting tube was clamped before the blood clotted and the blood flow stopped. Collected blood was immediately transported to the blood bank where it was separated into blood components, as RBCs and plasma.

\section{Separation and RBC unit preparation}

Collected UCB was stored under standard storage conditions $\left(2-6{ }^{\circ} \mathrm{C}\right)$ and processed within $24 \mathrm{~h}$ of collection. In all, 30 newborn (10 preterm and 20 full-term) UCB and 31 ADB units were collected. UCB and ADB units were centrifuged at $2600 \mathrm{~g}$ for $5.5 \mathrm{~min}$. Whole blood was then separated into plasma and buffy coat depleted RBCs using a blood component separation device. The total collected volume of UBC packed red cell concentrate (UCB-PRC) and 31 ADB-PRC samples were recorded. Then, $8 \mathrm{~mL}$ of blood from the main bag was transferred to each of 2 accessory bags. Blood samples for testing were withdrawn from the accessory bags to avoid contamination of the main bag on $\mathrm{d} 21$ and d 35. All blood units were stored in the same blood bank refrigerator at $4{ }^{\circ} \mathrm{C}$.

\section{Biochemical tests}

Biochemical (2,3-biphosphoglycerate [2,3-BPG], adenosine triphosphate [ATP], free $\mathrm{Hb}, \mathrm{K}^{+}$, and $\mathrm{pH}$ ) parameters were measured in all UCB-PRC samples on d 1, 21, and 35 of storage. Data were compared with data obtained from 31 ADB-PRC samples stored under the same conditions. Microbiological testing was performed on all samples via blood cultures using the Bactec system. The recommended blood volume (2 mL) was injected into 50-mL Bactec NR 660 aerobic and anaerobic pediatric blood culture bottles (Becton Dickinson, Franklin Lakes, NJ, USA). Inoculation of the samples was performed every week. Cultures were assessed daily for the presence of bacterial growth for 1 week after inoculation. Serum $\mathrm{K}^{+}$was measured via ion-selective electrode (ISE Olympus AU 600, Hamburg, Germany)

\section{ATP Measurement}

Intracellular ATP was measured via bioluminescence assay. The test principle is based on luciferase from Photinus pyralis (American firefly) catalyzing the following reaction:

$\mathrm{ATP}+\mathrm{D}$-luciferin $+\mathrm{O}_{2} \rightarrow$ oxyluciferin $+\mathrm{PPi}+\mathrm{AMP}+\mathrm{CO} 2$ + light.

The methods specified in the commercial kit (ATP Bioluminescence Assay Kit CLS II, Roche Cat. No. 1699695) were used.

\section{2,3-BPG measurement}

2,3-BPG was measured spectrophotometrically based on the change in absorbency at $340 \mathrm{~nm}$ caused by oxidation from NADH to NAD due to glycerol-3-phosphate dehydrogenase (GDH), according to the methods specified in the commercial kit (2,3-biphosphoglycerate Kit, Roche, Cat. No.10148334001).

\section{Free $\mathrm{Hb}$ measurement}

Free $\mathrm{Hb}$ was measured spectrophotometrically, as described previously [6].

\section{Statistical analysis}

Data analysis was performed using SPSS v.11.5. As the variables 2,3-BPG, ATP, $\mathrm{K}+$, and $\mathrm{pH}$ were not normally distributed, Friedman's ANOVA followed by Wilcoxon test with Bonferroni correction was used to determine the differences within groups, based on time. The differences of measured variables between UCB and ADB was analyzed using the non-parametric Mann-Whitney U test with Bonferoni correction [7].

In that case 3 different tests were performed to reduce the error made by Bonferroni correction and thus, $\mathrm{P}<$ $0.05 / 3=\mathrm{P}<0.017$ was considered statistically significant; when analyzing differences between 2 different time points, this level was accepted as $\mathrm{P}<0.05 / 2=\mathrm{P}<0.025$, as 2 different tests were performed.

\section{Results}

\section{Characteristics of the collected and processed blood}

The volume of UCB collected ranged between 43 and $94 \mathrm{~mL}$, depending on gestational age. The harvested UCB volume was $43-77 \mathrm{~mL}$ (mean: $57.1 \pm 10.5 \mathrm{~mL}$ ) for pre- 
term newborns and 62-94 mL (mean: $77.8 \pm 10.5 \mathrm{~mL}$ ) for full-term newborns. Birth weight was associated with the volume of collected UCB; approximately $24.8 \mathrm{~mL}$ of UCB $\mathrm{kg}^{-1}$ of bodyweight was collected, irrespective of gestational age. Mean RBC volume, on the other hand, was $14.6 \pm$ $2.4 \mathrm{~mL} \mathrm{~kg}^{-1}$ for the preterm newborns and $12.6 \pm 1.5 \mathrm{~mL}$ $\mathrm{kg}^{-1}$ for the full-term newborns.

\section{Microbial contamination}

Bacterial contamination was not observed in any of the UCB or ADB units during storage.

\section{Changes during storage}

Storage parameters for the $30 \mathrm{UCB}-\mathrm{PRC}$ and 31 ADBPRC samples are shown in Table 2. The $\mathrm{K}^{+}$level increased with time in both groups, with significant differences between $\mathrm{d} 1$ and 21 , and between $\mathrm{d} 1$ and 35 . Initial and d 21 levels were higher in the UCB samples than in the ADB samples (Table 3). The 2,3-BPG level did not differ significantly between UCB-PRC and ADB-PRC samples (P $>0.017)$; however, there was a significant decrease $(\mathrm{P}<$ 0.01) on d 21 and d 35-as compared to d 1-in both groups (Table 4).
On d 35 of storage free $\mathrm{Hb}$ (Table 5), pH (Table 6), and intracellular ATP values (Table 7) differed significantly from the initial values in both UCB and ADB RBCs. Significant differences in these parameters were also observed between UCB-PRC and ADB-PRC.

\section{Discussion}

The present study aimed to evaluate changes in UCBPRC and ADB-PRC in an additive storage medium (CPD) during storage. This preclinical study was considered to be essential for determining the feasibility of the clinical use of UCB. No transfusions were performed with the blood units collected during this study; however, the use of UCB for transfusion has been studied previously. Tamayo [8] reported the successful transfusion of 12 unfractionated UCB specimens (volume: 25-150 mL) in 1966 and suggested that UCB could be used instead of allogeneic transfusion. Ballin et al. published a case report describing how transfusion of 2 units of autologous UCB in a preterm baby did not cause any side effects [9]. In addition to the publication by Anderson et al. [10], Strauss published a warning on the clinical use of UCB, in which he suggested that the relative risks due to infections, changes during

Table 1: Characteristics of the neonates and UCB volume.

\begin{tabular}{|c|c|c|c|c|}
\hline $\begin{array}{c}\text { Birth weight } \\
(\mathrm{g})\end{array}$ & $\mathrm{n}$ & $\begin{array}{c}\text { Gestational age } \\
\text { (weeks) }\end{array}$ & $\begin{array}{c}\text { Mean UCB } \\
\text { Volume }(\mathrm{mL})\end{array}$ & $\begin{array}{c}\text { Mean RBC } \\
\text { Volume }(\mathrm{mL})\end{array}$ \\
\hline $1500-1999$ & 4 & $31.4 \pm 0.4$ & $49.0 \pm 7.6$ & $25.2 \pm 3.9$ \\
\hline $2000-2499$ & 6 & $31.9 \pm 0.2$ & $62.6 \pm 8.5$ & $32.9 \pm 5.7$ \\
\hline $2500-2999$ & 4 & $39.4 \pm 0.7$ & $74.3 \pm 7$. & $40.1 \pm 6.0$ \\
\hline $3000-3999$ & 15 & $38.9 \pm 1.0$ & $77.9 \pm 10.9$ & $41.7 \pm 3.4$ \\
\hline 4000 & 1 & 39 & 92 & 52 \\
\hline
\end{tabular}

Table 2: Mean hematological and biochemical parameters.

\begin{tabular}{|c|c|c|c|c|c|c|}
\hline & \multicolumn{2}{|c|}{ Day 1} & \multicolumn{2}{|c|}{ Day 21} & \multicolumn{2}{|c|}{ Day 35} \\
\hline & $\mathrm{UCB}$ & ADB & $\mathrm{UCB}$ & ADB & $\mathrm{UCB}$ & $\mathrm{ADB}$ \\
\hline $\mathrm{K}^{+}\left(\mathrm{mmol} \mathrm{L} \mathrm{L}^{-1}\right)$ & $6.5 \pm 2.2$ & $3.50 \pm 0.2$ & $35.9 \pm 3.7$ & $33.1 \pm 4.0$ & $38.3 \pm 5.0$ & $40.5 \pm 3.1$ \\
\hline 2,3-BPG $\left(\mathrm{mmol} \mathrm{L}^{-1}\right)$ & $1.2 \pm 0.4$ & $1.1 \pm 1.0$ & $0.2 \pm 0.1$ & $0.2 \pm 0.2$ & $0.2 \pm 0.1$ & $0.2 \pm 0.3$ \\
\hline Free $\mathrm{Hb}\left(\mathrm{g} \mathrm{dL}^{-1}\right)$ & $20.8 \pm 2.7$ & $21.1 \pm 2.2$ & $28.0 \pm 2.3$ & $22.3 \pm 1.8$ & $28.0 \pm 2.2$ & $30 \pm 2.5$ \\
\hline $\begin{array}{l}\text { Intracellular ATP } \\
\left(\mathrm{mmol} \mathrm{L}^{-1}\right)\end{array}$ & $\begin{array}{c}1 \pm 0.3 x \\
10^{-7}\end{array}$ & $\begin{array}{c}1.3 \pm 0.4 x \\
10^{-7}\end{array}$ & $\begin{array}{c}0.2 \pm 0.7 x \\
10^{-7}\end{array}$ & $\begin{array}{c}0.5 \pm 0.5 x \\
10^{-7}\end{array}$ & $\begin{array}{c}0.0 \pm 0.02 x \\
10^{-7}\end{array}$ & $\begin{array}{c}0.3 \pm 0.1 \times \\
10^{-7}\end{array}$ \\
\hline $\mathrm{pH}$ & $6.5 \pm 0.2$ & $7.0 \pm 0.0$ & $6.3 \pm 0.1$ & $6.7 \pm 0.0$ & $6.2 \pm 0.1$ & $6.6 \pm 0.1$ \\
\hline $\begin{array}{l}\text { Bacterial } \\
\text { Contamination }\end{array}$ & $\varnothing$ & $\varnothing$ & $\varnothing$ & $\varnothing$ & $\varnothing$ & $\varnothing$ \\
\hline
\end{tabular}


Table 3: Comparison of $\mathrm{K}^{+}$values in $\mathrm{UCB}$ and ADB samples over time.

\begin{tabular}{|c|c|c|c|c|c|}
\hline & Day 1 & Day 21 & Day 35 & $\begin{array}{c}\text { P Values in each } \\
\text { group }\end{array}$ & $\begin{array}{c}\text { P Values Between } \\
\text { Groups }\end{array}$ \\
\hline $\begin{array}{l}\mathrm{UCB} \\
\left(\mathrm{mmol} \mathrm{L}^{-1}\right)\end{array}$ & $\begin{array}{c}6.5 \pm 2.2 \\
(3.2-10.6)\end{array}$ & $\begin{array}{c}35.9 \pm 3.7 \\
(27.5-40.1)\end{array}$ & $\begin{array}{l}38.3 \pm 5.0 \\
(34.6-54.2)\end{array}$ & $\begin{array}{l}\text { Days 1-21 } \\
\mathrm{P}<0.001 \\
\text { Days } 1-35 \\
\mathrm{P}<0.001 \\
\text { Days } 21-35 \\
\mathrm{P}>0.05\end{array}$ & $\begin{array}{l}\text { Day } 1 \\
\mathrm{P}<0.001 \\
\text { Day } 21\end{array}$ \\
\hline $\begin{array}{l}\text { ADB } \\
\left(\mathrm{mmol} \mathrm{L}^{-1}\right)\end{array}$ & $\begin{array}{l}3.5 \pm 0.2 \\
(2.9-3.7)\end{array}$ & $\begin{array}{l}33.1 \pm 4.0 \\
(24.6-37)\end{array}$ & $\begin{array}{c}40.5 \pm 3.1 \\
(33.3-46.6)\end{array}$ & $\begin{array}{l}\text { Days 1-21 } \\
\mathrm{P}<0.05 \\
\text { Days } 1-35 \\
\mathrm{P}<0.001 \\
\text { Days } 21-35 \\
\mathrm{P}>0.05\end{array}$ & $\begin{array}{l}P=0.01 \\
\text { Day } 35 \\
P=0.1\end{array}$ \\
\hline
\end{tabular}

Table 4: Comparison of 2,3,-BPG values in UCB and ADB samples over time.

\begin{tabular}{|c|c|c|c|c|c|}
\hline & Day 1 & Day 21 & Day 35 & $\begin{array}{l}\text { P Values in each } \\
\text { group }\end{array}$ & $\begin{array}{c}\text { P Values Between } \\
\text { Groups }\end{array}$ \\
\hline $\begin{array}{l}\mathrm{UCB} \\
\left(\mathrm{mmol} \mathrm{L}^{-1}\right)\end{array}$ & $\begin{array}{l}1.2 \pm 0.4 \\
(0.5-2.1)\end{array}$ & $\begin{array}{l}0.2 \pm 0.1 \\
(0.1-0.6)\end{array}$ & $\begin{array}{l}0.2 \pm 0.1 \\
(0.1-0.6)\end{array}$ & $\begin{array}{c}\text { Days } 1-21 \\
P<0.001 \\
\text { Days } 1-35 \\
P<0.001 \\
\text { Days } 21-35 \\
P>0.05\end{array}$ & $\begin{array}{c}\text { Day } 1 \\
P=0.026 \\
\text { Day } 21\end{array}$ \\
\hline $\begin{array}{l}\text { ADB } \\
\left(\mathrm{mmol} \mathrm{L}^{-1}\right)\end{array}$ & $\begin{array}{l}1.1 \pm 1.0 \\
(0.7-3.9)\end{array}$ & $\begin{array}{l}0.2 \pm 0.2 \\
(0.0-0.8)\end{array}$ & $\begin{array}{l}0.2 \pm 0.3 \\
(0.1-1.9)\end{array}$ & $\begin{array}{c}\text { Days } 1-21 \\
P<0.001 \\
\text { Days } 1-35 \\
P<0.001 \\
\text { Days } 21-35 \\
P>0.05\end{array}$ & $\begin{array}{c}P=0.038 \\
\text { Day } 35 \\
P=0.035\end{array}$ \\
\hline
\end{tabular}

storage, and efficacy-as compared to allogeneic transfusions-should be clarified before the start of clinical studies [11].

Eichler et al. studied VLBW infants (body weight $<1000$ g) and collected a net mean UCB volume of only 37 $\mathrm{mL}$; RBC preparation was successful only in exceptional cases. They did conclude that the preparation of autologous RBCs from UCB collected from preterm infants was technically possible [12]. One of the concerns of UCB has been the small volume of blood collected. Researchers have tried to show the correlation between the volume of collected blood and birth weight, type of delivery (vaginal or caesarean section), and collection method (ex utero versus in utero) [12-19]. Despite some inconsistent results, Surbek et al. [14,15], Pafumi et al. [16,17], and Solves et al. [19] reported that in utero collection after caesarean delivery yielded higher collection volume. As such, in utero collection was employed in the present study.

Some studies examined the correlation between the volume of collected blood, and birth weight and gestational age of newborns. Garritsen et al. and Brune et al. harvested approximately $20 \mathrm{~mL} \mathrm{~kg}^{-1}$ of bodyweight, independent of birth weight, using both in utero and ex utero collection $[20,21]$. Eichler et al., on the other hand, reported 
Table 5: Comparison of free Hb values in UCB and ADB samples over time.

\begin{tabular}{|c|c|c|c|c|c|}
\hline & Day 1 & Day 21 & Day 35 & $\begin{array}{l}\text { P Values in each } \\
\text { group }\end{array}$ & $\begin{array}{c}\text { P Values Between } \\
\text { Groups }\end{array}$ \\
\hline $\begin{array}{c}\text { UCB } \\
\left(\mathrm{g} \mathrm{dL}^{-1}\right)\end{array}$ & $\begin{array}{c}20.8 \pm 2.7 \\
(15-25)\end{array}$ & $\begin{array}{c}28.0 \pm 2.3 \\
(22.8-31.7)\end{array}$ & $\begin{array}{c}28.0 \pm 2.0 \\
(23.3-31.3)\end{array}$ & $\begin{array}{c}\text { Days } 1-21 \\
\mathrm{P}<0.001 \\
\text { Days } 1-35 \\
\mathrm{P}<0.001 \\
\text { Days } 21-35 \\
\mathrm{P}>0.05\end{array}$ & $\begin{array}{c}\text { Day } 1 \\
\mathrm{P}=0.61 \\
\text { Day } 21\end{array}$ \\
\hline $\begin{array}{c}\mathrm{ADB} \\
\left(\mathrm{g} \mathrm{dL}^{-1}\right)\end{array}$ & $\begin{array}{c}21.2 \pm 2.2 \\
(16.9-23.6)\end{array}$ & $\begin{array}{c}22.3 \pm 1.8 \\
(18.6-27)\end{array}$ & $\begin{array}{c}30.0 \pm 2.5 \\
(25.4-33.8)\end{array}$ & $\begin{array}{c}\text { Days } 1-21 \\
P>0.05 \\
\text { Days } 1-35 \\
P<0.001 \\
\text { Days 21-35 } \\
P<0.001\end{array}$ & $\begin{array}{c}\mathrm{P}<0.001 \\
\text { Day } 35 \\
\mathrm{P}=0.017\end{array}$ \\
\hline
\end{tabular}

Table 6: Comparison of $\mathrm{pH}$ values in UCB and ADB samples over time.

\begin{tabular}{|c|c|c|c|c|c|}
\hline & Day 1 & Day 21 & Day 35 & $\begin{array}{c}\text { P Values in each } \\
\text { group }\end{array}$ & $\begin{array}{c}\text { P Values Between } \\
\text { Groups }\end{array}$ \\
\hline UCB & $\begin{array}{l}6.5 \pm 0.2 \\
(6.2-7.0)\end{array}$ & $\begin{array}{l}6.3 \pm 0.1 \\
(6.1-6.4)\end{array}$ & $\begin{array}{l}6.2 \pm 0.1 \\
(6.0-6.3)\end{array}$ & $\begin{array}{c}\text { Days } 1-21 \\
\mathrm{P}<0.001 \\
\text { Days } 1-35 \\
\mathrm{P}<0.001 \\
\text { Days } 21-35 \\
\mathrm{P}>0.05\end{array}$ & Days \\
\hline $\mathrm{ADB}$ & $\begin{array}{l}7.0 \pm 0.0 \\
(7.0-7.1)\end{array}$ & $\begin{array}{l}6.7 \pm 0.0 \\
(6.7-6.8)\end{array}$ & $\begin{array}{l}6.6 \pm 0.1 \\
(6.5-6.7)\end{array}$ & $\begin{array}{c}\text { Days } 1-21 \\
P<0.01 \\
\text { Days } 1-35 \\
P<0.001 \\
\text { Days } 21-35 \\
P>0.05\end{array}$ & $\begin{array}{c}1,21 \text { and } 35 \\
P<0.001\end{array}$ \\
\hline
\end{tabular}

Table 7: Comparison of ATP values in UCB and ADB samples over time.

\begin{tabular}{|c|c|c|c|c|c|}
\hline & Day 1 & Day 21 & Day 35 & $\begin{array}{l}\text { P Values in each } \\
\text { group }\end{array}$ & $\begin{array}{c}\text { P Values Between } \\
\text { Groups }\end{array}$ \\
\hline $\begin{array}{c}\mathrm{UCB} \\
\left(\mathrm{mmol} \mathrm{L}^{-1}\right)\end{array}$ & $\begin{array}{l}1.0 \pm 0.3 \times 10^{-7} \\
\left(0.3-1.6 \times 10^{-7}\right)\end{array}$ & $\begin{array}{c}0.2 \pm 0.7 \times 10^{-7} \\
\left(0.0-2.1 \times 10^{-7}\right)\end{array}$ & $\begin{array}{l}0.0 \pm 0.2 \times 10^{-7} \\
\left(0.0-0.5 \times 10^{-7}\right)\end{array}$ & $\begin{array}{c}\text { Days 1-21 } \\
P>0.05 \\
\text { Days } 1-35 \\
P<0.001 \\
\text { Days } 21-35 \\
P<0.001\end{array}$ & $\begin{array}{c}\text { Day } 1 \\
\mathrm{P}=0.029 \\
\text { Day } 21\end{array}$ \\
\hline $\begin{array}{c}\text { ADB } \\
\left(\mathrm{mmol} \mathrm{L}^{-1}\right)\end{array}$ & $\begin{array}{l}1.3 \pm 0.4 \times 10^{-7} \\
\left(0.5-2.1 \times 10^{-7}\right)\end{array}$ & $\begin{array}{l}0.5 \pm 0.5 \times 10^{-7} \\
\left(0.3-2.1 \times 10^{-7}\right)\end{array}$ & $\begin{array}{l}0.3 \pm 0.1 \times 10^{-7} \\
\left(0.0-0.5 \times 10^{-7}\right)\end{array}$ & $\begin{array}{l}\text { Days 1-21 } \\
P>0.05 \\
\text { Days 1-35 } \\
P<0.001 \\
\text { Days 21-35 } \\
P<0.001\end{array}$ & $\begin{array}{c}\mathrm{P}=0.021 \\
\text { Day } 35 \\
\mathrm{P}<0.001\end{array}$ \\
\hline
\end{tabular}


that there was an inverse correlation between the volume of collected blood, and gestational age and birth weight. They harvested $43 \mathrm{~mL} \mathrm{~kg}^{-1}$ of body weight from preterm infants [12]. Surbek et al. collected a median volume of $21 \mathrm{~mL}$ (range: 8-38 mL) following delivery of infants with a gestational of 22-32 weeks and a median volume of 49 $\mathrm{mL}$ (range: 21-103 mL) after delivery of infants with a gestational age of 33-36 weeks; birth weight and the volume of collected blood were not correlated $[14,15]$. Jansen et al. reported a UCB collection volume of $23 \mathrm{~mL} \mathrm{~kg}^{-1}$ in infants with a gestational age $<32$ weeks, but did not note a correlation between the volume of harvested UCB, and gestational age, birth weight, placental weight, or method of delivery [22]. Khodabux et al. observed a correlation between the collected blood volume and gestational age. The collected volume of UCB was $32 \pm 7.7 \mathrm{~mL}$ for infants with a gestational age of 24-28 weeks, $44 \pm 27.4 \mathrm{~mL}$ for those with a gestational age 28-30 weeks, and $33 \pm 13.3$ $\mathrm{mL}$ for infants with gestational age of 30-32 weeks. The volume of harvested UCB was $16 \pm 15 \mathrm{~mL} \mathrm{~kg}^{-1}$ in infants with a birth weight $<1000 \mathrm{~g}, 18 \pm 18 \mathrm{~mL} \mathrm{~kg}^{-1}$ for those weighing 1000-1250 g, and $20 \pm 23 \mathrm{~mL} \mathrm{~kg}^{-1}$ for those with a birth weight $>1250$ g; however, birth weight and the volume of harvested blood were not correlated [23]. Mean volume of harvested UCB in the present study was $57.11 \pm 10.46 \mathrm{~mL}$ in the preterm infants and 77.84 $\pm 10.54 \mathrm{~mL}$ in the full-term infants, and was $24.87 \mathrm{~mL}$ $\mathrm{kg}^{-1}$ of bodyweight, irrespective of gestational age. Mean $\mathrm{RBC}$ volume, on the other hand, was $14.63 \pm 2.43 \mathrm{~mL}$ $\mathrm{kg}^{-1}$ in the preterm infants and $12.55 \pm 1.46 \mathrm{~mL}$ in the full-term newborns, which is similar to previous reports. Mean UCB volume $\mathrm{kg}^{-1}$ of birth weight was higher in the preterm infants; however, correlation analysis between the collected volume, and birth weight and gestational age was not performed.

Numerous studies reported that $\mathrm{K}^{+}, 2,3-\mathrm{BPG}$, ATP, and $\mathrm{pH}$ values in stored blood and blood components change with time, and research has been conducted in an effort to increase the quality of stored blood [24-30]. Studies on the biochemical and hematological properties of stored UCB, however, are less common. Garritsen et al. studied whether or not UCB-PRC could be used as an alternative to ADB-PRC. They developed a system for collecting and preparing UCB-PRC, and measured standard storage parameters during $35 \mathrm{~d}$ of storage in extended storage medium (SAG mannitol). The initial laboratory UCB-PRC parameters were similar to those of ADB-PRC. After $35 \mathrm{~d}$ of storage UCB-PRC had a hemolysis rate $1 \%$ higher than that of ADB-PRC and a significant decrease in ATP. UCB-
PRC met the same quality criteria as ADB-PRC after $35 \mathrm{~d}$ of storage [20].

Bifano et al. studied 'placental whole blood' stored in CPDA for $28 \mathrm{~d}$ and reported that the $\mathrm{K}^{+}$level on $\mathrm{d} 28$ was comparable to that in stored ADB. In the UCB ATP, 2,3-BPG, and $\mathrm{pH}$ decreased, and some morphological changes, an increase in osmotic fragility, and a minimal increase in hemolysis were noted. They also reported that fetal erythrocytes were preserved better in citrate-phospohate-adenine-1 solution (CPDA-1) than in CPD [31]. The hemolysis rate, however, was higher in the studies by Brune et al. [32], Garritsen et al. [20], and Widing et al. [33]. In a recent review Khodabux and Brand reported that the preservative solution used, not the manipulation of UCB, might contribute to storage damage. This has been suggested by some other studies that reported better results using the storage solution PAGGSM that contained additional phosphate and guanosine than those obtained using SAG-M [34].

In the present study the 2,3-BPG level did not differ significantly between UCB-PRC and ADB-PRC ( $\mathrm{P}>$ 0.017). After $35 \mathrm{~d}$ of storage, free $\mathrm{Hb}$, intracellular ATP, and $\mathrm{pH}$ values were significantly different than initial values in both UCB RBCs and ADB RBCs. Additionally, it was observed that 2,3-BPG, ATP, and $\mathrm{pH}$ values decreased in both blood groups, whereas $\mathrm{K}^{+}$increased. These significant differences in both blood groups were thought to have been due to an increase in hemolysis and decrease in intracellular ATP. The higher $\mathrm{K}^{+}$value on $\mathrm{d} 1$ of storage reached a similar level in ADB on d 35. Bacterial contamination has been one of the concerns of the groups dealing working with UCB. In the present study bacterial contamination was not observed in any of the stored UCB-PRC samples. Eichler et al. had raised concerns with regard to the high rate of bacterial contamination [12]. Garritsen et al. [20] reported a bacterial contamination rate of $1.84 \%$ in 390 collected UCB units, and Jansen et al. reported there was bacterial contamination in 6 of 91 (7\%) collected UCB units stored for 30 days [22].

In conclusion, the volume of harvested and prepared UCB-PRC is similar to previous studies and can supply for some of the blood transfusions required in neonatal period and thus, its use may decrease number of allogeneic transfusions, especially in premature newborns. Hematological and biochemical changes that occur to UCB during storage are comparable to those observed in $\mathrm{ADB}$ and do not pose a risk to the relatively immature metabolism of neonates [35-37]. The lack of any observable bacterial contami- 
nation in the present study indicates that the collection method employed was reliable. The present findings show that the collection, separation, and storage of UBC-PRC, and the changes that occur during $35 \mathrm{~d}$ of storage can yield a product that is feasible for use under clinical conditions. In addition, autologous transfusion is safer than allogeneic transfusion, in terms of immunohematology and infection risk. The use and outcomes of UCB however, remain to be determined by further clinical studies.

Abbreviations: VLBW: Very low birth weight, UCB: Umbilical cord blood, ADB: Adult donor blood, RBC: Red BloodCell, $\mathrm{K}^{+}$:Potassium, 2,3-BPG:2,3-biphosphoglycerate, ATP: Adenosine tri-phosphate, UCB-PRC: Umbilical cord blood-packed red blood cell concentrate, A-PRC: Adult packed red blood cell concentrate, CPD: Citrate-phosphatedextrose additive solution

This study has been supported by Ankara University Scientific Research Projects Fund

\section{References}

1. Holland BM, Jones JG, Wardrop CA. Lessons from the anaemia of prematurity. Hematol Oncol Clin North Am 1987;1 (3): 355-366

2. Shannon KM. Anaemia of Prematurity : Progress and prospects. Am J Pediatr Hematol Oncol 1990; 12: 14-20

3. Ramasethu J, Luban NL. Red Blood Cell transfusion in the newborn. Seminars in Neonatology 1999; 4: 5-16

4. Nathanson N. Emergence of new viral infections: Implications for the blood supply. Biologicals 1998; 26 (2): 77-84

5. Chamberland ME. Surveillance for blood borne infections. Thromb Haemost 1999: 82: 494-499

6. Van Kampen E, Zijlstra WG. Standardization of hemoglobinometry: II. The hemiglobincyanide method. Clin Chim Acta 1961; 6: 538-544

7. Siegel S, Castellan Jr. NJ. Nonparametric Statistics For The Behavioral Sciences. New York: McGraw-Hill Inc., 1998

8. Tamayo JG. The use of residual placental blood for transfusion. J Philipp Med Assoc 1966; 42 (7): 399-406

9. Ballin A, Arbel E, Kenet G, Berar M, Kohelet D, Tanay A, Zakut H, Meytes D. Autologous umbilical cord blood transfusion. Arch Dis Child Fetal Neonatal Ed 1995: 73: 181-183

10. Anderson S, Fangman J, Wager G, Uden D. Retrieval of placental blood from umbilical vein to determine volume, sterility and presence of clot formation. Am J Dis Child 1992; 146 (1): 36-39
11. Strauss RG. Autologous transfusions for neonates using placental blood. A cautionary note. Am J Dis Child 1992; 146 (1): $21-22$

12. Eichler H, Schaible T, Richter E., Zeiger W, Voller K, Leveringhaus A, Goldmann SF. Cord blood as a source of autologous RBC's for transfusion to preterm infants. Transfusion 2000; 40: 1111-1117

13. Reboredo N, Diaz A, Castro A, Villaescusa RG. Collection, processing and cryopreservation of umbilical cord blood for unrelated transplantation. Bone Marrow Transplant 2000; 26: $1263-1270$

14. Surbek DV, Glanzmann R, Senn HP, Hoesli I, Holzgreve W. Can cord blood be used for autologous transfusion in preterm neonates? Eur J Pediatr 2000; 159 (10): 790-791

15. Surbek DV, Holzgreve W, Steinmann C, Hahn S, Gratwohl A, Wodnar-Filipowicz A, Tichelli A. Preterm birth and the availability of cord blood for HPC transplantation. Transfusion 2000; 40: 817-820

16. Pafumi C, Farina M, Bandiera S, Cavallaro A, Pernicone G, Russo A, Iemmola A, Chiarenza M, Leonardi I, Calogero AE, Calcagno A, Cianci A. Differences in umbilical cord blood units collected during cesarean section, before or after the delivery of the placenta. Gynecol Obstet Invest 2002; 54: 73-77

17. Pafumi C, Milone G, Maggi I, Mancari R, Farina M, Russo A, Pernicone G, Bandiera S, Giardina P, Franceschini A, Calogero AE, Cianci A. Umbilical cord blood collection in Cesarean section: A comparison before and after placental delivery. Arch Gynecol Obstet 2002; 266: 193-194

18. Sparrow RL, Cauchi JA, Ramadi LT, Waugh CM, Kirkland MA. Influence of mode of birth and collection on WBC yields of umbilical cord blood units. Transfusion 2002; 42: 210-215

19. Solves P, Mirabet V, Larrea L, Moraga R, Planelles D, Saucedo E, Uberos FC, Planells T, Guillen M, Andres A, Monleon J, Soler MA, Franco E. Comparison between two cord blood collection strategies. Acta Obstet Gynecol Scand 2003; 82: $439-442$

20. Garritsen HS, Brune T, Louwen F, Wüllenweber J, Ahlke C, Cassens U, Witteler R, Sibrowski W. Autologous red cells derived from cord: collection, preparation, storage and quality controls with optimal additive storage medium (Sagmannitol). Transfus Med 2003; 13: 303-310

21. Brune T, Garritsen H, Hentschel R, Louwen F, Harms E, Jorch G. Efficacy, recovery and safety of RBCs from autologous placental blood: Clinical experience in 52 newborns. Transfusion 2003; 43: 1210-1216

22. Jansen M, Brand A, von Lindern JS, Scherjon S, Walther FJ. Potential use of autologous umbilical cord blood red cells for early transfusion needs of premature infants. Transfusion 2006; 46: 1049-1056 
23. Khodabux CM, von Lindern JS, van Hilten JA, Scherjon S, Walther FJ, Brand A. A clinical study on the feasiblility of autologous cord blood transfusion for anemia of prematurity. Transfusion 2008; 48: 1634-1643

24. Wallas $\mathrm{CH}$. Sodium and potassium changes in blood bank stored human erythrocytes. Transfusion 1979; 19: 210-215

25. Moroff G, Dende D. Characterization of biochemical changes occuring during storage of red cells. Comparative studies with CPD and CPDA-1 anticoagulant-preservative solutions. Transfusion 1983; 23: 484-489

26. Hess JR, Greenwalt TG. Storage of blood cells: New approaches. Transfus Med Rev 2002; 16: 283-295

27. Sezdi M, Baylk M, Ülgen Y. Storage effect on the Cole-Cole parameters of erythrocyte suspensions. Physiol Meas 2006; 27: 623-635

28. Högman CF, Löfh H, Meryman HT. Storage of Red Blood cells with improved maintenance of 2,3- Bisphosphoglycerate. Transfusion 2006; 46: 1543-1552

29. Yoshida T, AuBuchon JP, Dumont LJ, Gorham JD, Gifford SC, Foster KY, Bitensky MW. The effects of additive solution $\mathrm{pH}$ and metabolic rejuvenation on anaerobic storage of red cells. Transfusion 2008; 48: 2096-2105

30. de Korte D, Kleine M, Korsten HG, Verhoeven AJ. Prolonged maintenance of 2,3-diphopsphoglycerate acid and adenosine triphosphate in red blood cells during storage. Transfusion 2008; 48: 1081-1089

31. Bifano EM, Dracker RA, Lorah K, Palit A. Collection and 28-day storage of human placental blood. Pediatr Res 1994; 36: $90-94$
32. Brune T, Garritsen H, Witteler R, Schlake A, Wüllenweber J, Louwen F, Jorch G, Harms E. Autologous placental blood transfusion for the therapy of anaemic neonates. Biol Neonate 2002: 81: 236-243

33. Widing L, Bechensteen AG, Mirlashari MR, Vetlesen A, Kjeldsen-Kragh J. Evaluation of nonleukoreduced red blood cell transfusion units collected at the delivery from the placenta. Transfusion 2007; 47: 1481-1487

34. Khodabux CM, Brand A. The use of cord blood for transfusion purposes: Current status. Vox Sang 2009; 97: 281-293

35. Parshuram CS, Joffe AR. Prospective study of potassiumassociated acute transfusion events in pediatric intensive care. Pediatr Crit Care Med 2003; 4: 65-68

36. Vohra HA, Adluri K, Willets R, Horsburgh A, Barron DJ, Brawn WJ. Changes in potassium concentration and hematocrit associated with cardiopulmonary bypass in paediatric cardiac surgery. Perfusion 2007; 22: 87-92

37. Dani C, Perugi S, Benuzzi A, Corsini I, Bertini G, Pratesi S, Rubaltelli FF. Effects of red blood cell transfusions during the first week of life on acid-base, glucose and electrolytes in preterm neonates. Transfusion 2008; 48: 2302-2307 